\title{
DETERMINING RELATION BETWEEN GALLSTONE AND LIPID PROFILE
}

\author{
Singh $R R^{1^{*}}$, Adhikari SC ${ }^{1}$, Bastakoti $R^{1}$, Giri $K^{1}$, Regmi $S^{2}$, Baskota $R^{3}$
}

\section{Affiliation}

1. Consultant Surgeon, Department of Surgery, Koshi Zonal Hospital, Nepal

2. Consultant Uro-Surgeon, Department of Surgery, Koshi Zonal Hospital, Nepal

3. Consultant Dermatologist, Department of Dermatology, Koshi Zonal Hospital, Nepal.

\section{ARTICLE INFO \\ Article History \\ Received : 11 February, 2018 \\ Accepted : 18 August, 2018 \\ Published : 31 August, 2018}

(C) Authors retain copyright and grant the journal right of first publication with the work simultaneously licensed under Creative Commons Attribution License CC - BY 4.0 that allows others to share the work with an acknowledgment of the work's authorship and initial publication in this journal.

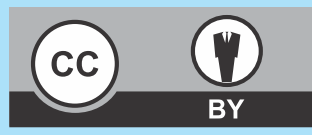

\section{ORA 67}

DOI: http://dx.doi.org/10.3126/bjhs.v3i2.20937

\section{* Corresponding Author}

Dr. Rabin Raj Singh

Consultant Surgeon

Department of Surgery, Koshi Zonal Hospital, Nepal

Email: singhrabinraj@gmail.com

ORCID: https://orcid.org/0000-0001-6453-3453

\section{Citation}

Singh RR, Adhikari SC, Bastakoti R, Giri K, Regmi S, Baskota R. Determining Relation Between gallstone and Lipid Profile. BJHS 2018;3(2)6:418-422.

\section{ABSTRACT}

\section{Introduction}

Cholelithiasis is presence of stone in gallbladder. Female sex, obesity, pregnancy, fatty foods, all are associated with an increased risk of developing gallstones. There is paucity of information regarding relation of cholelithiasis and lipid profile. In this study the association of serum lipids to cholelithiasis has been tried to been elucidated.

\section{Objectives}

The general objective was to determine the relation of Serum lipid in cholelithiasis. The specific objectives were to compare the relation between serum cholesterol, serum triglyceride, serum HDL and serum LDL in patients with and without gallstones.

\section{Methodology}

A prospective, observational, hospital based study was conducted at Koshi Zonal Hospital from March 2017 to Feburary 2018. Fifty four patients having gallstone (Group A) were compared with equal number of patients without gallstone (Group B). Data was entered into SPSS/MS Excel. Statistical Analysis was done by using Chi-square test. A 95\% confidence interval was taken, and $P$ value less than 0.05 was considered as statistically significant.

\section{Results}

In Group A, 61\%(33) patients were of age less than 45 years and $91 \%(49)$ were female. In group A, 3.7 \%(2) and in group $B, 7.4 \%(4)$ had raised serum cholesterol. Greater number of patient in group $A$ had raised serum triglyclyceride and $L D L$ as compared to group B. $18.5 \%(10)$ of group A had low serum HDL, and $9.3 \%$ (5) of group B had low serum HDL. Except for finding of gallstone more common in female, other findings had no statistical significance.

\section{Conclusion}

There exists an inverse correlation between Serum Cholesterol and serum HDL with gallstone and positive association between serum Triglyceride and serum LDL with cholelithiasis. However the association could not reach the statistical significance.

\section{KEY WORDS}

Cholelithiasis, gallstone, serum lipid 


\section{INTRODUCTION}

Cholelithiasis is presence of stone in gallbladder. Gallstone disease (GSD) is one of the most common gastrointestinal diseases seen in clinical practice. Female sex, obesity, pregnancy, fatty foods, Crohn's disease, terminal ileal resection, gastric surgery, hereditary spherocytosis, sickle cell disease, and thalassemia are all associated with an increased risk for developing gallstones. ${ }^{2}$ However, only first-degree relatives of patients with gallstones and obesity (body mass index $>30 \mathrm{~kg} / \mathrm{m}^{2}$ ) have been identified as strong risk factors for development of symptomatic gallstone disease. ${ }^{3}$ Prevalence has been found to $11 \%$ to $36 \%$ in autopsy. ${ }^{4}$

Gallstones are among the most common gastrointestinal illness requiring hospitalization. Approximately $1-2 \%$ of asymptomatic patients will develop symptoms requiring cholecystectomy per year, making cholecystectomy one of the most common operations performed by general surgeons. ${ }^{5}$ Gallstones in patients without biliary symptoms are commonly diagnosed incidentally on ultrasonography, CT scans, abdominal radiography, or at laparotomy.

There are three types of gallstones, Cholesterol, Pigment and mixed. By definition cholesterol gallstones contain more than $70 \%$ cholesterol whereas pigment stones contain $<20 \%$ cholesterol. Whereas those containing intermediate amounts of cholesterol are labeled as mixed stones. Whether it be cholesterol or mixed stones, the common primary event in the formation of gallstones is supersaturation of bile with cholesterol. Therefore, high bile cholesterol levels and cholesterol gallstones are considered as one disease.

\section{METHODOLOGY}

This was a prospective, observational and hospital based study conducted at Koshi Zonal Hospital. study period was one year from March 2017 to Feburary 2018. Using LDL cholesterol values from the study Correlation of Serum Lipids and Glucose Tolerance Test in Cholithiasis,-Standard deviation (SD) for control is 10.2 and for cases is 23.8 , with power of $80 \%$ and level of significance of 0.05 , true difference of population means assumed to be 10 , sample size for each group was 54 (Russ length power and sample size). Over a period of study, first 54 patients admitted to the hospital with the diagnosis of cholelithaisis for cholecystectomy formed $1^{\text {st }}$ group whereas $2^{\text {nd }}$ group was constituted by admitted 54 patients with diagnosis other than cholelithiasis. The diagnosis of cholelithaisis and absence of cholelitaisis was based on Ultrasonography finding. Group A: Patients with gallstone and Group B: Patient without gallstone were include in the study. Children $<15$ yrs, pancreatitis, cholangitis, diabetes, cardiac disease(Myocardial infarction, CHD, Angina pectoris), renal disease and others with serious illness (Perforation peritonitis, Strangulated Hernia) were excluded from the study. Data of the study conducted was obtained from history and physical examination as well as the completed pro forma mainly by the principal investigator after meeting all the criteria mentioned. Upon receiving a case fulfilling the inclusion criteria, the participants were explained about the study in detail. He or she was assured of full confidentiality and a written informed consent taken subsequently. On admission Fasting venous blood samples was collected under strict aseptic precautions with informed consent. Serum total cholesterol, HDL cholesterol, triglycerides, levels were estimated by ERBA fully automated biochemistry analyzer. $L D L$ calculated with following formula $L D L=$ Total cholesterol -(triglyceride/5+HDL). Interim analysis of data was performed upon completion of the study. These data were entered into the computer using SPSS and Microsoft Excel Software. Statistical Analysis were done by using Chi-square test and Fisher's exact test. Data were expressed in the form of tables and charts where feasible. A 95\% confidence interval were taken, and $P$ value less than 0.05 was termed as statistically significant. Ethical clearance was obtained from the concerned authority.

\section{RESULTS}

Fifty-four cases (Group A) and equal number of controls (Group B) were included in the study. In group A 61\%(33) patients were of less than 45 years of age whereas $39 \%(21)$ patients were of more than 45 years. Similarly in Group B, $52 \%$ (28) were of less than 45 years and $48 \%(26)$ were of more than 45 years.

In group A, 91\%(49) were female and 9\%(5) were male. In group B $70 \%(38)$ were female and $30 \%(16)$ were male.

\begin{tabular}{lccc}
\multicolumn{3}{c}{ Table 1: Odds ratios (with 95\% confidence interval) } \\
\multicolumn{1}{c}{ Age } & OR & Lower & Up\% Cl \\
\hline 45 yrs & 1.459 & 0.679 & 3.134 \\
$>45$ yrs & Ref & & \\
$\begin{array}{l}\text { Sex } \\
\text { Female }\end{array}$ & 4.132 & 1.386 & 12.345 \\
Male & Ref & & \\
\hline
\end{tabular}

Probability of having gallstone in those who are less than 45 yrs is 1.459 (0.679-3.134) times higher than those who are more than 45 yrs of age. Probability of having gallstone in female is 4.132 (1.386-12.345) times higher than male.

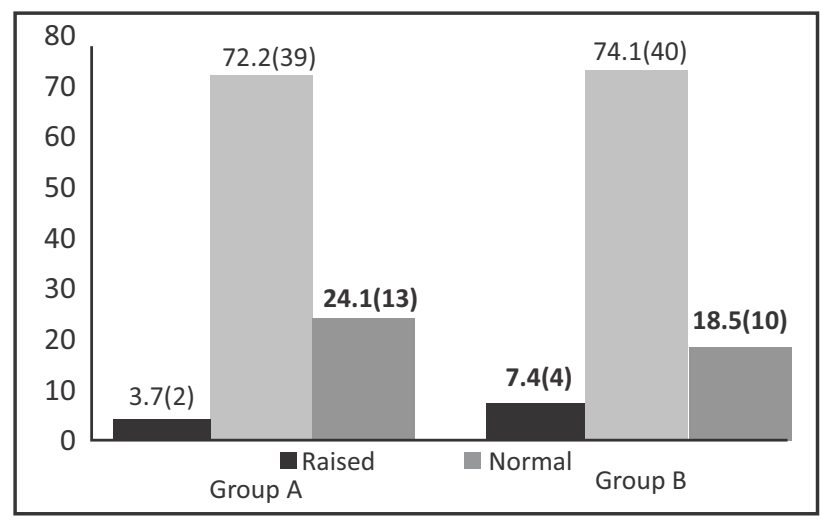

Figure : Distribution of Serum Cholesterol in group $A$ and group B. 
In group A, 72\% (39) cases had cholesterol level in normal range whereas $4 \%(2)$ had increased serum cholesterol and $24 \%$ (13) had lower serum cholesterol. Among non gallstone group B 74\% (40) had normal serum cholesterol whereas $7 \%(4)$ had raised level and $19 \%(10)$ had lowered serum cholesterol.

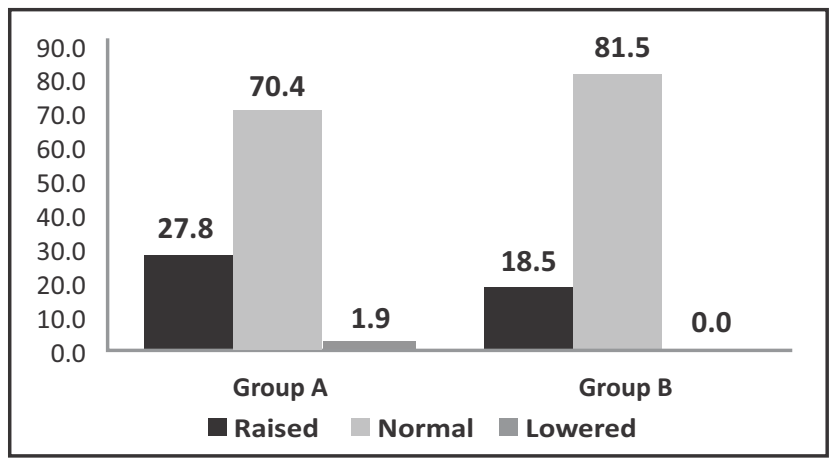

Figure 4 : Distribution of Serum Triglyceride in group A and group $B$

In Gallstone group, 28\%(15) had raised serum triglyceride where as $70 \%$ (38) had normal and $2 \%$ (1) had low serum triglyceride. In Group B $19 \%(10)$ had raised serum triglyceride whereas $81 \%$ (44) had had normal serum triglyceride.

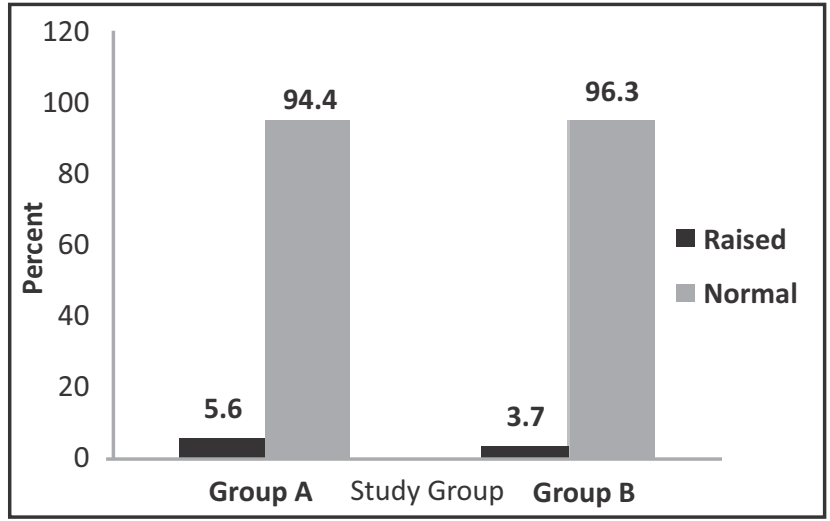

Figure 5 : Distribution of Serum LDL in group A and group B

Among Group A patient 6\% (3) had raised serum LDL and $94 \%$ (51) had normal serum LDL. In group B $4 \%$ (2) had raised where as $96 \%$ (52)had normal serum LDL level.

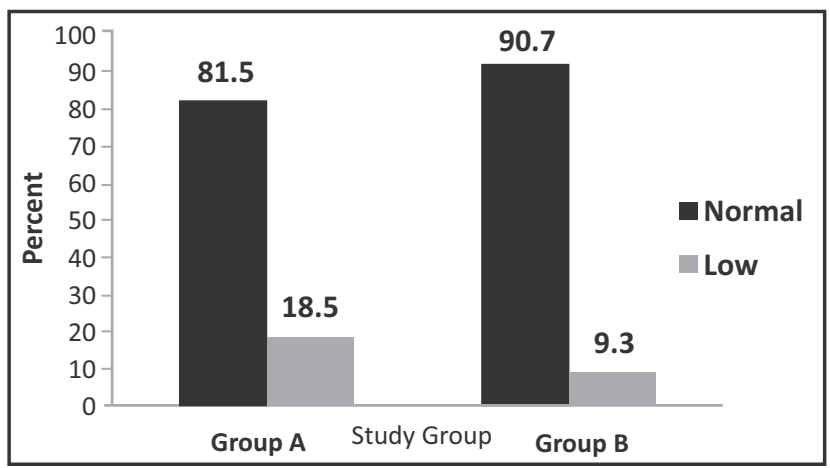

Figure 6 : Distribution of Serum HDL in group A and group B

In Gallstone group 82\% (44) had normal where as 18\% (10) had low Serum HDL. Similarly in Group B 91\% (49) had normal Serum HDL where as 9\% (5) had low values.

Table 2: Comparasion of raised serum cholesterol in
Group A and Group B.
\begin{tabular}{l|c|c|c|c|c|c|c} 
Serum & Group A & \multicolumn{2}{c}{ Group B } & \multicolumn{2}{c}{ Total } \\
Cholesterol & N & $\%$ & N & $\%$ & N & $\%$ \\
\hline raised & 2 & 3.7 & 4 & 7.4 & 6 & 5.6 \\
\hline not raised & 52 & 96.3 & 50 & 92.6 & 102 & 94.4 \\
\hline Total & 54 & 100.0 & 54 & 100.0 & 108 & 100.0 \\
p-value: 0.678
\end{tabular}

Lesser number of patients $3.7 \%$ (2) in group A had raised serum cholesterol than group B 7.4\%, (4),giving an Odds ratio of 0.481 (0.084-2.742.

Further analysis was done by combining normal and low values of serum triglyceride and was termed as not raised. This was compared with the raised value to obtain odd ratio.

Table 3: Comparasion of raised serum triglyceride in
Group A and Group B.
\begin{tabular}{|l|c|c|c|c|c|c|c|}
\hline $\begin{array}{c}\text { Serum } \\
\text { triglyceride }\end{array}$ & \multicolumn{2}{|c|}{ Group A } & \multicolumn{2}{c|}{ Group B } & \multicolumn{2}{c|}{ Total } \\
\hline raised & 15 & 27.8 & 10 & 18.5 & 25 & 23.1 \\
\hline not raised & 39 & 72.2 & 44 & 81.5 & 83 & 76.9 \\
\hline Total & 54 & 100.0 & 54 & 100.0 & 108 & 100.0 \\
\hline
\end{tabular}

$27.8 \%$ (15)of group A has raised serum triglyclyceride and only $18.5 \%$ (10) of group B have raised serum triglyclyceride giving an Odds ratio of 1.692 (0.682-4.199). ( $p$-value: 0.254) Further analysis was done by comparing normal values of serum LDL and was termed as not raised. This was compared with the raised value to obtain odd ratio.

Table 4 : Comparasion of raised serum LDL in Group A
and Group B
\begin{tabular}{|l|l|l|l|l|l|l|l|}
\hline \multirow{3}{*}{ Serum LDL } & Gall stone & \multicolumn{2}{c|}{ Total } \\
\cline { 2 - 8 } & \multicolumn{3}{|c|}{ Group A } & \multicolumn{2}{c|}{ Group B } & \multicolumn{1}{c|}{} \\
\cline { 2 - 8 } & N & $\%$ & N & $\%$ & N & $\%$ \\
\hline Raised & 3 & 5.6 & 2 & 3.7 & 5 & 4.6 \\
\hline not raised & 51 & 94.4 & 52 & 96.3 & 103 & 95.4 \\
\hline Total & 54 & 100.0 & 54 & 100.0 & 108 & 100.0 \\
\hline
\end{tabular}

In only 5.6\% (3) of group A showed raised serum LDL where as $3.7 \%$ (2) of group $B$ had increased serum LDL giving an Odds ratio of 1.529 (0.245-9.538). ( P-value: 1.000)

Further analysis was done by comparing Lower values of serum HDL and was termed as not raised. This was compared with the raised value to obtain odd ratio.

Table 5 : Comparasion of raised serum HDL in Group A
and Group B
\begin{tabular}{|c|c|c|c|c|c|c|}
\hline Serum & Group A & \multicolumn{2}{c|}{ Group B } & \multicolumn{2}{|c|}{ Total } \\
\cline { 2 - 7 } LDL & N & $\%$ & N & $\%$ & N & $\%$ \\
\hline Normal & 44 & 81.5 & 49 & 90.7 & 93 & 86.1 \\
\hline Low & 10 & 18.5 & 5 & 9.3 & 15 & 13.9 \\
\hline Total & 54 & 100.0 & 54 & 100.0 & 108 & 100.0 \\
\hline
\end{tabular}

Though $18.5 \%$ (10) of group A had low serum HDL only 9.3 (5) of group B had low serum HDL giving an Odds ratio of $2.22(0.706-7.04)$. (p-value: 0.164$)$ 
Table 6 : Mean and Standard deviation of Lipid profile in Group A and Group B

\begin{tabular}{|c|c|c|c|c|c|c|c|}
\hline \multirow{2}{*}{$\begin{array}{l}\text { Lipid } \\
\text { Profile }\end{array}$} & \multicolumn{2}{|c|}{ Group A } & \multicolumn{2}{|c|}{ Group B } & \multicolumn{2}{|c|}{ Total } & \multirow[t]{2}{*}{ p-value* } \\
\hline & Mean & $\begin{array}{c}\text { Std. } \\
\text { Deviation }\end{array}$ & Mean & $\begin{array}{c}\text { Std. } \\
\text { Deviation }\end{array}$ & Mean & $\begin{array}{c}\text { Std. } \\
\text { Deviation }\end{array}$ & \\
\hline $\begin{array}{l}\text { Serum } \\
\text { Cholesterol }\end{array}$ & 168.06 & 35.215 & 178.44 & 43.212 & 173.25 & 39.578 & 0.174 \\
\hline $\begin{array}{l}\text { Serum } \\
\text { Triglyceride }\end{array}$ & 133.28 & 69.616 & 121.98 & 49.367 & 127.63 & 60.332 & 0.333 \\
\hline Serum LDL & 96.52 & 29.297 & 90.87 & 27.330 & 93.69 & 28.340 & 0.303 \\
\hline Serum HDL & 42.19 & 10.146 & 45.89 & 11.856 & 44.04 & 11.139 & 0.084 \\
\hline
\end{tabular}

*independent sample t-test

Table 6 gives the average values of Lipids in the forms of means and their Standard deviation. The table shows higher values of Serum Cholesterol and Serum HDL in group B. while Serum Triglyceride and Serum LDL are found to be more in group $A$.

\section{DISCUSSION}

Gall stone disease is one of the common problems attending in surgical outpatient department. The chief constituents of gallstones are cholesterol, bilirubin and calcium.1 Other constutientsmay include fatty acids, triglycerides, protein and polysaccharides. In the great majority of stones encountered in the Western world, the principal constituent is cholesterol, which usually comprises 70 to 98 per cent of the dried substance of the stone.Lipids, such as cholesterol and triglyceride are insoluble in plasma. They are made soluble by attachment to circulating lipoproteins that transport lipids to various tissues for energy utilization, lipid deposition, steroid hormone production, and bile acid formation. A standard serum lipid profile measures the concentration of total and HDLcholesterol (HDL-C) as well as the triglycerides. In our study we have studied on different variables like age, sex, and serum lipids including serum cholesterol, serum triglyceride, serum low density lipoprotein and serum high density lipoprotein.

Age is a major risk factor for the gallstones. Gallstones are exceedingly rare in children except in the presence of hemolytic states; in addition, less than 5 percent of all cholecystectomies are performed in children. Age 40 appears to represent the cut-off between relatively low and high rates of cholecystectomies. This observation was validated in the Sirmione study in which the incidence between the ages of 40 and 69 years was four times higher than that in younger subjects. ${ }^{7}$ In our study we found that $61 \%$ of patients belonged to $<45$ years and $39 \%$ belonged to $>45$ years.

Sex is also one of the risk associated with gall stone. A higher prevalence of gallstones has been observed in women in all age groups. ${ }^{8}$ In our study also $61 \%$ of the patient were $<45$ years of age and females predominated in those age group as prevalence cholelithiasis is common in fatty fertile Female of forty. In our study we found probability of having gallstone in those who are less than 45 years was
1.46 times higher than those who are more than 45 yrs of age. As well as probability of having gallstone in female is 4.132 times higher than males The higher rates in young women is almost certainly a result of pregnancy and sex steroids but the actual cause is yet to be delineated and we have not considered these factors in our study.

There are various studies which have shown variability in the association between gallstone and serum lipids. Gallstones appear to be positively associated with apolipoprotein E4 phenotype and elevated serum triglycerides. ${ }^{9-11}$ In contrast, a negative association exists between gallstones and high density lipoprotein. There is no conclusive evidence linking elevated serum cholesterol and gallstones. ${ }^{12}$ In the study performed by Naseem et al Serum lipid profile were determined in 109 gallstone patients and 100 controls revealed no significant variation except for the triacylglycerols and total lipids, which were differed significantly between females of up to 45 and above 45 years age. ${ }^{13}$ We found that $24 \%$ of the cholelithiasis patient had low serum cholesterol, where as only $4 \%$ of them had increase cholesterol level And in $7.4 \%$ of those who did not have gall stone had raised serum cholesterol and $18.5 \%$ had low serum cholesterol level. In a prospective study performed by Kumari et al in a population of Guntur city and compared 82 patients of cholelithiasis cases 117 control subjects of healthy males. Their result showed gall stone was associated with low serum cholesterol and HDL and high serum Triglyceride level which was comparable to our study. ${ }^{14}$ This inverse relationship between serum cholesterol level and gallstone disease was also shown by Maria Ximena et al who concluded that an increment in the catabolic pool of cholesterol, reflected in lower levels of plasma cholesterol in subjects with gallstone disease. ${ }^{15}$

In our study $27.8 \%$ of cholelithiasis patient had raised serum triglyceride and only $18.5 \%$ of control subjects showed raised serum triglyceride level with odds ration of 1.69 , though this result was not statistically significant. In Sivakumaran et al increased level of triglyceride level was seen in gallstone patient in both sexes of all age group. ${ }^{16}$ They have also shown raised level of cholesterol in patient with gall stones which was just the opposite to our study. Devesa et al have reported a positive association between gallstone and serum triglyceride in Spanish men. ${ }^{17}$

In our study $5.6 \%$ of cholelithiasis patient had raised serum Low Density Lipoprotein as compared to only $3.7 \%$ of control group showed serum LDL. Similar association between LDL and Chlelithiasis has been shown by various other studies. Chapma et al found a positive association between gallstone disease and serum triglyceride, serum LDL cholesterol and decreased HDL cholesterol all of which were comparable to our results. ${ }^{18}$

In our study serum HDL was low in $18.5 \%$ of gallstone patient whereas it was low only in $9.3 \%$ of control subjects. 
Most of the studies have shown similar association between HDL and gallstone. Chen et al. also found a positive association between gallstone disease and decreased HDL cholesterol level. ${ }^{18}$ Similar results as shown by Kumari et al who compared 82 patients of cholelithiasis cases 117 control subjects showed gall stone was associated with low serum cholesterol and HDL and high serum Triglyceride level which was comparable to our study. ${ }^{14}$

Different study showed a positive association between gallstone disease and increased level of serum triglyceride and LDL cholesterol and decreased HDL cholesterol. ${ }^{18-19}$ Our study also showed the similar association which could not reach statistical significance.

\section{CONCLUSION}

There exist an inverse correlation between serum Cholesterol and serum HDL with gallstone and positive association between serum triglyceride and serum LDL with cholelithiasis. However the association could not reach the statistical significance

\section{RECOMMENDATION}

The main objective behind this research is to determine the relationship between serum lipid and gallstone. Based on this study dietary risk factors associated with gallstone disease can be formulated that will help in prevention and management of gallstone disease.

\section{CONFLICT OF INTEREST}

We declare no conflict of interest.

\section{FINANCIALDISCLOSURE}

None

\section{REFERENCES}

1. A. B. Olokob BJB, I. A. Katibi, A. K. Salami, L. B. Olokoba, K. T. Braimoh, A. K. Inikori. Relationship between gallstone disease and serum lipids in normal adult Nigerians. African Scientist. September 30, 2006;7(3):113-6.

2. Bellows CF BD, Crass RA. Management of gallstones. Am Fam Physician 2005. 2005;72:637-42. PIMD: 16127953

3. Nakeeb A CA, Martin L. Gallstones: Genetics versus environment. Ann Surg 2002;235:842-9. PIMD: 12035041

4. Brett M, Barker DJ. The world distribution of gallstones. Int J Epidemiol. 1976 Dec;5(4):335-41. PMID: 1010661

5. Conlon K. The Gall bladder and bile ducts. 25th edition ed. Norman S. Williams CJKB, P. Ronan o' Connell, editor. London: Edward Arnold Ltd.; 2008.

6. Kleeberg J. Experimental studies on the colloid biochemical mechanism of gallstone formation. Gastroenterology 1953(80):336-7.PMID: 13128217

7. Barbara L, Sama C, Labate AM, Taroni F, Rusticali AG, Festi D, Sapio C, Roda E, Banterle C, Puci A, Formentini F. A population study on the prevalence of gallstone disease: theSirmione Study. Hepatology. 1987 Sep 1;7(5):913-7. PMID: 3653855

8. Maurer KR EJ, Ezzati TM. Prevalence of gallstone disease in Hispanic populations in the United States. Gastroenterology 1989;96:487. PMID:2642879

9. Thijs C KP, Brombacher P. Serum lipids and gallstones: a case-control study. Gastroenterology 1990;99:843.PMID:2379787

10. Scragg RK CG, Oliver JR. Plasma lipids and insulin in gall stone disease: a case-control study. Br Med J 1984;289:521. PMID: 6432171

11. Halldestam I KE, Borch K. Incidence of and potential risk factors for gallstone disease in a general population sample. Br J Surg. 2009; 96:1315.PMID:19847878
12. Marks JW CP, Albers JJ. Lack of correlation between serum lipoproteins and biliary cholesterol saturation in patients with gallstones. Dig Dis Sci. 1984;29:1118.https://doi. org/10.1007/ BF01317086

13. Channa NA, Ghanghro AB, Soomro AM. Quantitative analysis of serum lipid profile in gallstone patients and controls. Pakistan Journal of Analytical \& Environmental Chemistry. 2010 Jun 1;11(1):7.

14. D. Jalaja Kumari BSHK. Role of Body Mass Index, Physical Activity and Nutrients in Cholelithiasis in Guntur, Andhra Pradesh. J Hum Ecol 2010;31(3):151-5.https://doi.org/10.1016/S0188-0128(99)00005-6

15. Duque-L MX, Morán S, Salmerón-Castro J, Rodríguez-Leal G, Ramos $\mathrm{ME}$, Uribe M. Inverse association between plasma cholesterol and gallstone disease. Archives of medical research. 1999 May 1;30(3): 190-7. DOI: https://doi.org/10.1016/S0188-0128(99)00005-6

16. Sivakumaran Sabanathana b, Soonita Oomeera, Lloyd R Jenkinsona. Cholecystectomy or Cholelithiasis- a Missed Marker fo rHyperlipidaemia? A Combined Retrospective and Prospective Study. Gastroen Res. 2008;1:29-32.doi: 10.4021/gr2008.11.1246

17. Devesa F, Ferrando J, Caldentey M, Borghol A, Moreno MJ, Nolasco A, Moncho J, Berenguer J. Cholelithiasic disease and associated factors in a Spanish population. Digestive diseases and sciences. $2001 \mathrm{Jul}$ 1;46(7):1424-36.https://doi.org/10.1023/A:1010631619162

18. Chapma BA WI, Frampton CM. Prevalence of gallbladder disease in diabetes mellitus Digestive Diseases and Sciences. 1996;41(11):2222 8. https://doi.org/10.1007/BF02071404

19. CY C. The risk factors for gallstone disease among senior citizens: An oriental study. Hepato-Gastroenterology 1999;46(27):107 1612.PMID:10430304 